\title{
Marmara Bölgesi’nin Bazı Yerleşim Merkezlerinde Halk İlacı Olarak Kullanılan Bitkiler
}

\author{
Emine Burcu YEŞiLYURT, Işıl ŞİMŞEK, Tuğba TUNCEL, Galip AKAYDIN, Erdem YEŞILADA
}

\begin{abstract}
Özet
Bu çalışmada, Bilecik-Aşağıköy, Bilecik-Pazaryeri-Büyük Elmalı, Bursa-Merkez, Edirne-Keşan-Kozköy, Edirne-Keşan ve Edirne-İpsala ilçelerinde ikamet eden ve araştırmaya gönüllü olarak katılmayı kabul eden 263 birey ile yüz yüze anket yöntemiyle görüşülmüş ve hazırlanan anket formlarında yer alan sorular yardımı ile araştırma için gerekli bilgiler toplanmıştır. Elde edilen bilgiler doğrultusunda, bitkilerin halk ilacı olarak kullanılan kısımları, kullanılış amaçları ve hazırlanış şekilleri (dekoksiyon, infüzyon, lapa, merhem vb.) sorgulanarak kaydedilmiştir.
\end{abstract}

Toplanan bitki örnekleri bilimsel olarak tanımlanmış ve
Hacettepe Üniversitesi Eğitim Fakültesi Herbaryumu'nda (HEF) muhafaza edilmektedir. Çalışmada 33 familyaya ait 68 taksonun halk ilacı olarak kullanıldığı tespit edilmiştir. Bunların çoğunluğunun Rosaceae (10 takson), Lamiaceae (8 takson), Asteraceae (7 takson) ve Poaceae (4 takson) familyalarına ait olduğu görülmüştür. Halk ilacı olarak kaydedilen 187 kullanım arasında en fazla; gastro-intestinal sistem (46 kullanım; \%24,6), solunum sistemi ve gögüs hastalıkları (41 kullanım; \%21,9), üriner sistem (18 kullanım; \%9,6), hematopoetik, immün sistem ve kanser (18 kullanım; \%9,6) yer almaktadır.

Anahtar kelimeler: Halk ilac1, Bilecik, Bursa, Edirne, Türkiye.
Emine Burcu Yeşilyurt

Hacettepe Üniversitesi, Fen Fakültesi, Biyoloji ABD, 06800, Beytepe / Ankara

Işı1 Şimşek

Gazi Üniversitesi, Eczacılık Fakültesi, Eczacıllk Temel Bilimleri ABD, 06330, Etiler / Ankara

Tuğba Tuncel

Türk Telekom Mesleki ve Teknik Anadolu Lisesi, 26110, Odunpazarı / Eskişehir

Galip Akaydın

Hacettepe Üniversitesi, Eğitim Fakültesi, Biyoloji Eğitimi ABD, 06800, Beytepe / Ankara

Erdem Yeşilada

Yeditepe Üniversitesi, Eczacıllk Fakültesi, Farmakognozi ve Fitoterapi ABD, 34755, Ataşehir / İstanbul

Corresponding author:

Erdem Yeşilada

E-posta: yesilada@yeditepe.edu.tr

Submitted / Gönderilme: 07.09.2016

Accepted / Kabul: 11.10.2016

Revised / Düzeltme: 07.10.2016

\section{Giriş}

Türkiye’nin kuzeybatısında yer alan Marmara Bölgesi farklı bir topografyaya, Kafkasyadan ve Balkanlar'dan aldığı göçler dolayısıyla da farklı etnik ve sosyoekonomik bir yapıya sahiptir (1). Gün geçtikçe teknolojide yaşanan gelişmeler, ulaşım kolaylığı, kentlere göç, sağlık hizmetlerine daha kolay erişim vb. faktörler etkisiyle etnik ve sosyoekonomik yapı değişmekte ve halk ilaçları ile ilgili bilgilere erişim zorlaşmaktadır. Geçmiş dönemde kayıtların tutulamaması, bunun yanı sıra yetişen neslin bu konuya ilgisiz kalması sonucu bilgiler giderek kaybolmaktadır. Türkiye’nin ve Marmara bölgesinin çeşitli kısımlarında bu konuda yapılmış çok sayıda çalışma bulunmasına karşılık, ülkemizin geniş yüzölçümü nedeniyle bu tip bilgilerin kapsamlı bir şekilde kayıt altına alınmasında çabalar yetersiz kalmaktadır (2-19). $\mathrm{Bu}$ nedenle, sahip oldukları coğrafi konum ve özellikleri ile gelişmiş ve gelişmekte olan yerleşim birimlerine ait halk ilaçları ile ilgili bilgilerin yok olmadan kayıt altına alınması yararlı olacaktır. 


\section{Gereç ve Yöntem}

Bu çalışma kapsamında Marmara Bölgesi’nde yer alan BilecikAşağıköy (n:35), Bilecik-Pazaryeri-Büyük Elmalı (n:15), Bursa-Merkez (n:100), Edirne-Keşan (n:34), Edirne-KeşanKozköy (n:46) ve Edirne-İpsala (n:33) ilçelerinde (Şekil 1) ikamet eden 263 birey ile daha önceki çalışmalarımızda (20-23) kullanılan anket formları uygulanarak yüz yüze görüşülmüştür. Anket formunda katılımcıların demografik özelliklerinin yanı sıra, halk ilacı olarak kullanılan yabani bitkilerin yöresel isimleri, kullanım amaçları, hazırlanış şekilleri, temin edilme kaynakları gibi sorular yer almaktadır. Anket formları uygulanırken, bireylerin yönlendirilmelerini engellemek amacıyla belli bir bitki veya hastalıkla ilgili bilgi sorulmamasina özen gösterilmiştir.

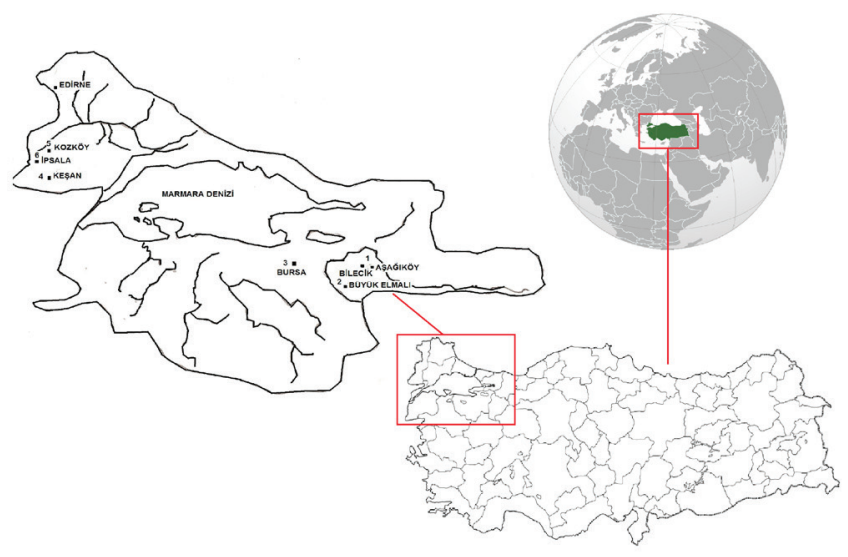

Şekil 1. 1.Bilecik / Aşağıköy; 2. Bilecik / Pazaryeri / Büyük Elmalı; 3. Bursa / Merkez; 4. Edirne / Keşan; 5. Edirne / Keşan / Kozköy; 6.Edirne / İpsala
Görüşmelerde genellikle takipçi gibi davranılarak katılımcılar evlerinde ziyaret edilmiş ve yabani bitkilerin kullanımıyla özel olarak ilgilenen komşularının toplanması rica edilmiştir. Bazı görüşmeler ise, erkeklerin bir arada bulundukları köy kahvesi veya cami bahçesinde yapılmıştır. Görüşmeden sonra katılımcıyla birlikte ilgili bitki örnekleri toplanmıştır.

Halk ilacı olarak kullanıldığı tespit edilen bitki örnekleri usulüne uygun şekilde toplanmış ve kurutularak herbaryum materyali haline getirilmiştir. Herbaryum materyali haline getirilen yabani bitkilerin teşhisinde "Flora of Turkey and The East Aegean Islands" (24-26), "Doğal Bitkilerimiz" (27), "Kayış Dağı'nın Çiçekleri” (28) ve "Beytepe Bitkileri” (29-30) gibi genel kaynaklardan yararlanılmıştır. İlgili materyaller Hacettepe Üniversitesi Eğitim Fakültesi Herbaryumu’nda (HEF) muhafaza edilmektedir.

Anket formları ile toplanan bilgiler, SPSS 16.0 programı kullanılarak değerlendirilmiş, düz ve çapraz tablolar oluşturulmuş, yüzde (\%) değerleri alınmıştır. Analizlerde Kikare testi kullanılmış ve $\mathrm{p}<0,05$ bulunan değerler istatistiksel olarak anlamlı kabul edilmiştir.

Sonuç ve Tartışma: Bireylere ait demografik özellikler Tablo 1'de gösterilmiştir. Tablo 1'de görüldüğü gibi araştırmaya katılan bireylerin \%65,4'ü kadın, \%34,6's1 ise erkektir. Katılımcıların \%26,2'si 30 yaş ve altında, geriye kalan $\% 73,8$ ' $\mathrm{i}$ ise 31 yaş ve üstündedir. Katılımcıların \%86,3’ü okuryazar, $\% 66,9^{\prime}$ u ise evlidir. Katılımcıların büyük çoğunluğunu ev hanımları $(\% 45,7)$ oluşturmaktadır. Bireylerin çoğunluğu $(\% 58,5)$ kursal kesimlerde ikamet etmekte ve $\% 89,0$ 'u da yaşadığı bölgede 10 yll ve üzeri süredir ikamet etmektedir.

Tablo 1. Bireylerin Demografik Özelliklerine Göre Dağılımı (n:263)

\begin{tabular}{|c|c|c|c|}
\hline Demografik Özellikler & & Sayı & Yüzde (\%) \\
\hline \multirow{2}{*}{ Cinsiyet } & Kadın & 172 & 65,4 \\
\hline & Erkek & 91 & 34,6 \\
\hline \multirow[t]{3}{*}{ Yaş } & 30 ve alt1 & 69 & 26,2 \\
\hline & $31-43$ aras 1 & 56 & 21,3 \\
\hline & 44 ve üzeri & 138 & 52,5 \\
\hline \multirow[t]{3}{*}{ Eğitim Durumu } & Okuryazar değil & 36 & 13,7 \\
\hline & İlköğretim mezunu & 115 & 43,7 \\
\hline & Lise ve yüksekokul & 112 & 426 \\
\hline \multirow[t]{2}{*}{ Medeni Durum } & Evli & 176 & 66,9 \\
\hline & Bekâr, dul, bosanmıs & 87 & 33,1 \\
\hline \multirow[t]{5}{*}{ Çalışma Durumu } & Ev hanımı & 120 & 45,7 \\
\hline & Serbest meslek & 69 & 26,2 \\
\hline & Memur & 34 & 12,9 \\
\hline & Öğrenci & 20 & 7,6 \\
\hline & Emekli & 20 & 7,6 \\
\hline \multirow[t]{2}{*}{ En Uzun Süre İkamet Edilen Yer } & Kırsal kesim & 154 & 58,5 \\
\hline & Kentsel kesim & 109 & 41,5 \\
\hline \multirow[t]{2}{*}{ Bölgede İkamet Süresi } & 10 yildan az & 29 & 11,0 \\
\hline & 10 yll ve üzeri & 234 & 89,0 \\
\hline
\end{tabular}


Bireylerin yabani bitkiler hakkında sahip oldukları bilgi ve tüketim durumları ile ilgili bulgular Tablo 2'de verilmiştir. Tablo 2'ye bakıldığında, araştırmaya katılanların büyük çoğunluğunun $(\% 84,4)$ bölgede yetişen yabani bitkiler hakkında bilgi sahibi olduğu görülmektedir. Bireylerin \%73,4'ü yabani bitki tüketmekte olup, \%26,6'sı ise yararlı olduğuna inanmadıkları, ihtiyaç duymadıkları veya yeterli bilgiye sahip olmadıkları için yabani bitki tüketmemektedir.

Tablo 2. Bireylerin yabani bitkilere ait bilgi ve tüketim durumları.

\begin{tabular}{|c|c|c|}
\hline & Sayı & Yüzde (\%) \\
\hline \multicolumn{3}{|l|}{ Bilgi Durumu (n:263) } \\
\hline Bilgisi var & 222 & 84,4 \\
\hline Bilgisi yok & 41 & 15,6 \\
\hline \multicolumn{3}{|l|}{ Tüketme Durumu (n:263) } \\
\hline Tüketiyor & 193 & 73,4 \\
\hline Tüketmiyor & 70 & 26,6 \\
\hline \multicolumn{3}{|l|}{ Tüketmeme Nedeni (n:70) } \\
\hline Yeterli bilgisi yok & 40 & 57,1 \\
\hline İhtiyaç duymuyor & 26 & 37,2 \\
\hline Yararlı olduğuna inanmıyor & 4 & 5,7 \\
\hline \multicolumn{3}{|l|}{ Tüketme Süresi (n:193) } \\
\hline 5 yildan az & 45 & 23,3 \\
\hline $5-10 \mathrm{yil}$ & 27 & 14,0 \\
\hline 11 yıl ve üzeri & 121 & 62,7 \\
\hline \multicolumn{3}{|l|}{ Temin Etme Şekli (n:193) } \\
\hline Kendisi topluyor & 106 & 54,9 \\
\hline Satın alıyor & 47 & 24,4 \\
\hline Hem topluyor hem satın alıyor & 40 & 20,7 \\
\hline \multicolumn{3}{|l|}{ Satın Alınan Yer (n:87) } \\
\hline Aktar & 51 & 58,6 \\
\hline Semt pazarı & 30 & 34,5 \\
\hline Market & 6 & 6,9 \\
\hline \multicolumn{3}{|l|}{ Toplama Saati (n:146) } \\
\hline Herhangi bir saatte & 93 & 63,7 \\
\hline Öğleden sonra & 25 & 17,1 \\
\hline Sabah & 28 & 19,2 \\
\hline \multicolumn{3}{|c|}{ Tüketme Alıșkanlığının Edinildiği Kaynak (n:193)* } \\
\hline Büyükler & 157 & 81,3 \\
\hline Kitle iletişim araçları & 47 & 24,4 \\
\hline Arkadaşlar & 25 & 13,0 \\
\hline Kitap, dergi vb. & 11 & 5,7 \\
\hline \multicolumn{3}{|l|}{ Tüketme Sıklığı (n:193) } \\
\hline Gerektiğinde & 110 & 57,0 \\
\hline Sürekli & 50 & 25,9 \\
\hline Mevsiminde & 33 & 17,1 \\
\hline \multicolumn{3}{|l|}{ Tüketim Amacı (n:193) } \\
\hline Halk ilacı & 158 & 81,9 \\
\hline Diğer (gıda, süs eşyası, koku-tat, boya vb.) & 35 & 18,1 \\
\hline \multicolumn{3}{|c|}{ Halk ilacı olarak kullanımda yan etki görülme durumu (n:158) } \\
\hline Hayır & 149 & 94,3 \\
\hline Evet & 9 & 5,7 \\
\hline \multicolumn{3}{|c|}{ Halk ilacı olarak kullanımda alınan sonuç (n:158) } \\
\hline Olumlu & 144 & 91,1 \\
\hline Olumsuz & 14 & 8,9 \\
\hline
\end{tabular}

* Birden çok seçenek işaretlenmiştir. 
11 yıl ve daha fazla süredir yabani bitki tüketenlerin oranı \%62,7'dir. Yabani bitki tüketenlerin \%54,9'u bitkileri kendisi toplamakta, \%24,4’ü toplanmış olarak satın almakta, \%20 ,7'si hem toplamakta hem de satın almaktadır. Yabani bitki satın alanların \%58,6’sı bitkileri aktardan, \%34,5’i semt pazarından, \%6,9'u ise marketten almaktadır.

Yabani bitki toplayanların \%19,2'si bitkileri sabah saatlerinde toplamayı tercih ettiği halde, \%63,7'sinin böyle bir zaman tercihi bulunmamaktadır. Bu bulgu, bireylerin çoğunluğunun bitki toplamaya yönelik doğru zaman konusunda bilgilerinin yeterli olmadığını göstermektedir.

Yabani bitki tüketen bireyler bu alışkanlığı çoğunlukla büyüklerinden $(\% 81,3)$ ve kitle iletişim araçlarından $(\% 24,4)$ kazanmaktadır. Yabani bitkileri tüketenlerin \%57,0'si gerektiğinde, \%17,1'i ise mevsiminde tüketmektedirler. Yabani bitkileri halk ilacı olarak kullanan bireylerin \%94,3’ü herhangi bir yan etki görmediğini ve \%91,1'i olumlu sonuç aldığını ifade etmiştir

Bireylerin demografik özelliklere göre yabani bitkileri bilme (Tablo 3) ve tüketme (Tablo 4) durumları ile ilgili bulgular birlikte incelenecek olursa: Araştırmaya katılan erkeklerin \%72,5'i yabani bitkiler hakkında bilgi sahibi iken, yabani bitki tüketen erkeklerin oranı \%60,4'tür. Bunun yanında kadınların \%90,7'si yabani bitkiler hakkında bilgi sahibi iken, yabani bitki tüketen kadınların oranı ise $\% 80,2$ 'dir.

Tablo 3. Bireylerin çeşitli faktörlere göre yabani bitkileri bilme durumları (n:263)

\begin{tabular}{|c|c|c|c|c|c|}
\hline & \multicolumn{3}{|c|}{ Biliyor } & \multicolumn{2}{|c|}{ Bilmiyor } \\
\hline & & Sayı & $\%$ & Sayı & $\%$ \\
\hline \multicolumn{6}{|l|}{ Cinsiyet } \\
\hline Kadin (n:172) & 156 & & 90,7 & 16 & 9,3 \\
\hline \multirow[t]{2}{*}{ Erkek (n:91) } & 66 & & 72,5 & 25 & 27,5 \\
\hline & \multicolumn{3}{|c|}{$\mathrm{p}=0,00^{*}$} & & \\
\hline \multicolumn{6}{|l|}{ Yaş (yıl) } \\
\hline 30 ve alt1 $(n: 69)$ & 45 & & 65,2 & 24 & 34,8 \\
\hline $31-43$ aras1 (n:56) & 42 & & 75,0 & 14 & 25,0 \\
\hline \multirow[t]{2}{*}{44 ve üstü (n:138) } & 135 & & 97,8 & 3 & 2,2 \\
\hline & $\chi^{2}=41,95$ & \multicolumn{2}{|l|}{$\mathrm{p}=0,00^{*}$} & & \\
\hline \multicolumn{6}{|l|}{ Eğitim durumu } \\
\hline Okuryazar değil (n:36) & 36 & & 100,0 & 0 & 0,0 \\
\hline İlköğrenim mezunu (n:115) & 105 & & 91,3 & 10 & 8,7 \\
\hline \multirow[t]{2}{*}{ Lise ve yüksekokul mezunu (n:112) } & 81 & & 72,3 & 31 & 27,7 \\
\hline & $\chi^{2}=23,24$ & \multicolumn{2}{|l|}{$\mathrm{p}=0,00^{*}$} & & \\
\hline \multicolumn{6}{|l|}{ Medeni durum } \\
\hline Evli (n:176) & 159 & & 90,3 & 17 & 9,7 \\
\hline \multirow[t]{2}{*}{ Bekâr, dul, boşanmış (n:87) } & 63 & & 72,4 & 24 & 27,6 \\
\hline & $\chi^{2}=14,21$ & \multicolumn{2}{|l|}{$\mathrm{p}=0,00^{\star}$} & & \\
\hline \multicolumn{6}{|l|}{ En uzun süre ikamet edilen yer } \\
\hline Kirsal kesim (n:154) & 147 & & 95,5 & 7 & 4,5 \\
\hline \multirow[t]{2}{*}{ Kentsel kesim (n:109) } & 75 & & 68,8 & 34 & 31,2 \\
\hline & $\chi^{2}=34,50$ & \multicolumn{2}{|l|}{$\mathrm{p}=0,00^{*}$} & & \\
\hline \multicolumn{6}{|l|}{ Bölgede ikamet süresi } \\
\hline \multirow{3}{*}{$\begin{array}{l}10 \text { yıldan az (n:29) } \\
10 \text { yıl ve üzeri (n:234) }\end{array}$} & \multirow{2}{*}{\multicolumn{2}{|c|}{$\begin{array}{r}21 \\
201\end{array}$}} & 72,4 & 8 & 27,6 \\
\hline & & & 85,9 & 33 & 14,1 \\
\hline & $\chi^{2}=3,56$ & $p=0,059$ & & & \\
\hline
\end{tabular}


Tablo 4. Bireylerin çeşitli faktörlere göre yabani bitkileri tüketme durumları (n:263)

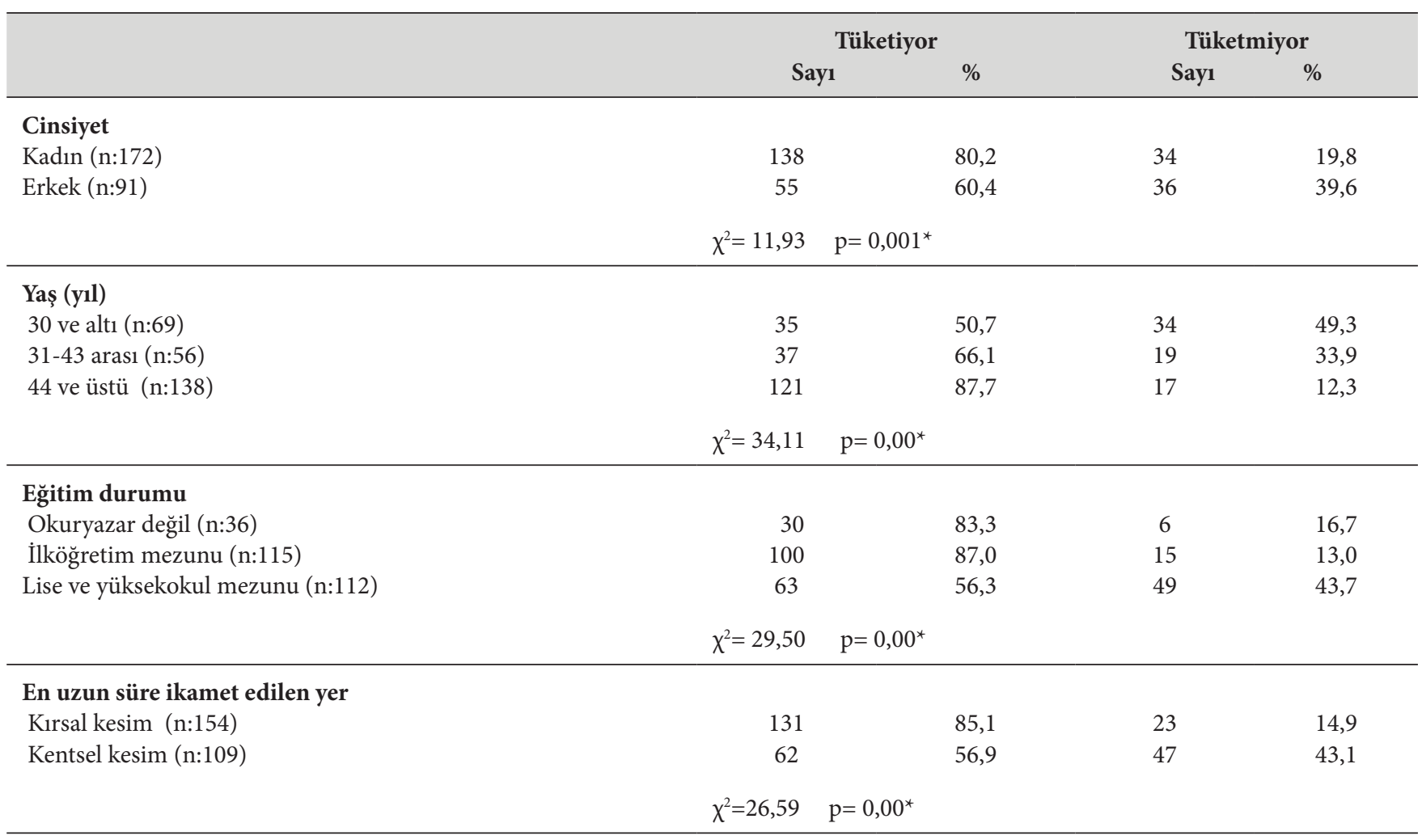

${ }^{*} \mathrm{p}<0.05$

44 yaş ve üzerindeki katılımcıların \%97,8'i yabani bitkiler hakkında bilgi sahibiyken, 30 yaş ve altındaki katılımcıların $\% 65,2$ 'si yabani bitkiler hakkında bilgi sahibidir. 44 yaş ve üzerindeki katılımcıların $\% 87,7$ 'si, 30 yaş ve altındaki katılımcların ise \%50,7'si yabani bitki tüketmektedir. Araştırmaya katılan fakat okuryazar olmayan bireylerin tamamı $(\% 100,0)$ yabani bitkiler hakkında bilgi sahibidir ve bu katılımcıların \%83,3’ü yabani bitki tüketmektedir. İlköğretim mezunu olan katılımcıların \%91,3’ü yabani bitkiler hakkında bilgi sahibiyken, bu katılımcıların \%87,0'si yabani bitki tüketmektedir. Kırsal kesimde ikamet eden bireylerin $\% 95,5$ i yabani bitkiler hakkında bilgi sahibiyken, bireylerden \%85,1'i yabani bitki tüketmektedir. Kentsel kesimde ikamet eden bireylerin ise $\% 68,8^{\prime} i$ yabani bitkiler hakkında bilgi sahibiyken, $\% 56,9^{\prime}$ u yabani bitki tüketmektedir.

Tablolardan da anlaşıldığı üzere, bireylerin yabani bitkiler hakkında ki bilgi (Tablo 3) ve tüketme durumlarının (Tablo 4) cinsiyet, yaş, eğitim durumu, en uzun süre ikamet edilen yere göre anlamlı fark gösterdiği saptanmıştır $(\mathrm{p}<0.05)$. Ayrıca, bireylerin yabani bitkiler hakkında bilgili olmaları (Tablo 3) da medeni duruma göre anlamlı fark göstermiştir.

Bireyler tarafından tüketilen ve bilimsel tanımlaması yapılan yabani bitkilere ait bulgular Tablo 5'te, hastalıkların farmakolojik etkilerine göre sinıflandırılması ise Tablo 6’da verilmiştir.

Anket uygulanan 263 bireyden 158 (\%60,1)'i bitkileri halk ilacı olarak kullanmaktadır. Halk ilacı olarak tüketilen bitkilerin, toprak üstü, kök, gövde, yaprak, çiçek, meyve, tohum gibi kısımları doğrudan yenilerek, lapa halinde, su ile kaynatılarak (dekoksiyon), kaynamış suya ilave edilerek (infüzyon), tohumu balla karıştırılarak ve benzeri yöntemlerle hazırlanarak ilgili hastalıkların tedavisinde kullanılmaktadır.

Araştırma alanında yetişen bitkiler arasında Urtica cinsine ait 2 türün (U. dioica L. ve $U$. urens L.) en fazla kullanıma sahip olduğu görülmektedir. Urtica cinsinin toprak üstü kısımları kanser, mide ülseri, mide ekşimesi, karın ağrısı, idrar yolları iltihabı, romatizma, astım, nezle, grip, öksürük, diyabet, sivilce, böbrek yetmezliği, mayasıl ve saç dökülmesi tedavisinde, ayrıca vücut direncini kuvvetlendirici ve ödem söktürücü olarak; tohumları kanser, menopoz, karın ağrısı, grip ve idrar yolları iltihabı tedavisinde; çiçekleri ise yanık tedavisinde kullanılmaktadır. Halk ilacı olarak kullanımı fazla olan bir diğer takson ise Hypericum perforatum L. 'dur. $\mathrm{Bu}$ taksonun toprak üstü kısımları mayasıl, yara, yanık, mide ağrısı, mide ekşimesi, öksürük ve soğuk algınlığı tedavisinde kullanılmaktadır. 
Tablo 5. Bireyler tarafından tüketilen ve bilimsel tanımlaması yapılan yabani bitkilere ait bulgular

\begin{tabular}{|c|c|c|c|c|c|c|}
\hline Latince isim & $\begin{array}{l}\text { Herbaryum } \\
\text { numaraları }\end{array}$ & Yöre* & Yöresel isim & Kullanılan kısım & Kullanım amacı & Hazırlama şekli \\
\hline \multicolumn{7}{|c|}{ Amaranthaceae } \\
\hline $\begin{array}{l}\text { Amaranthus } \\
\text { retroflexus L. }\end{array}$ & 07U01 & 1 & $\begin{array}{l}\text { Yağsız hıştır/ } \\
\text { Karasirken/ } \\
\text { Sirken }\end{array}$ & Yaprak & Kabızlık & Yemeği yapılır ve yenir. \\
\hline
\end{tabular}

Anacardiaceae

Dal

Cotinus coggyria $\quad 05 \mathrm{Y} 01$

Scop.

\begin{tabular}{|c|c|c|c|c|c|c|}
\hline & & \multirow{3}{*}{5} & \multirow{3}{*}{ Tetereağacı } & \multirow{2}{*}{\multicolumn{3}{|c|}{$\begin{array}{l}\text { Dallar ince ince doğranır, } \\
\text { dekoksiyon şeklinde } \\
\text { hazırlanır, süzülür. Ağız } \\
\text { gargarası olarak kullanılır. }\end{array}$}} \\
\hline & & & & & & \\
\hline & & & & Yaprak & Sulu yaralar & $\begin{array}{l}\text { Kurutulmuş yaprak ciltteki } \\
\text { yaranın üzerine konur. }\end{array}$ \\
\hline \multicolumn{7}{|l|}{ Apiaceae } \\
\hline $\begin{array}{l}\text { Coriandrum } \\
\text { sativum } \mathrm{L} .\end{array}$ & 07V02 & 2 & Kişniş & Tohum & Yüksek tansiyon & $\begin{array}{l}\text { Tohumları sabahları aç } \\
\text { karnına yenir. }\end{array}$ \\
\hline $\begin{array}{l}\text { Conium } \\
\text { maculatum L. }\end{array}$ & 05Y02 & 5 & Baldıran & Yaprak & Karın ağrısı (Çocukta) & $\begin{array}{l}\text { Yapraklar haşlanır ya da } \\
\text { tavada kavrulur, bir beze } \\
\text { sarılarak çocuğun karnı } \\
\text { üzerine koyulur. }\end{array}$ \\
\hline $\begin{array}{l}\text { Petroselinum } \\
\text { crispum (Miller) } \\
\text { A. W. Hill }\end{array}$ & 07U02 & 1 & Maydanoz & Toprak üstü & $\begin{array}{l}\text { İdrar yolları iltihabı, } \\
\text { yüksek kolesterol, } \\
\text { böbrek kumu }\end{array}$ & $\begin{array}{l}\text { Bir demet maydanoz, üç } \\
\text { limon, bir kilo elma, yedi } \\
\text { bardak su ile dekoksiyon } \\
\text { şeklinde hazırlanır ve aç } \\
\text { karnına sabah içilir. }\end{array}$ \\
\hline \multicolumn{7}{|l|}{ Asteraceae } \\
\hline $\begin{array}{l}\text { Achillea setacea } \\
\text { Waldst. Et Kit. }\end{array}$ & 07U03 & 1 & Ayvadana & Toprak üstü & Egzama & $\begin{array}{l}\text { Dekoksiyon şeklinde } \\
\text { hazırlanır ve içilir }\end{array}$ \\
\hline $\begin{array}{l}\text { Anacyclus clavatus } \\
\text { (Desf.) Pers. }\end{array}$ & $08 Z 01$ & 6 & Papatya & Çiçek & $\begin{array}{l}\text { Hazımsizlık ve mide } \\
\text { bulantısı }\end{array}$ & $\begin{array}{l}\text { Dekoksiyon şeklinde } \\
\text { hazırlanır ve günde } 1 \text { su } \\
\text { bardağı içilir. }\end{array}$ \\
\hline \multirow{2}{*}{$\begin{array}{l}\text { Anthemis cretica } \\
\text { L. } \\
\text { subsp. anatolica } \\
\text { (Boiss.) Grierson }\end{array}$} & \multirow[t]{2}{*}{ 07U04 } & \multirow{2}{*}{1} & \multirow{2}{*}{ Papatya } & \multirow{2}{*}{ Çiçek } & $\begin{array}{c}\text { Astım, bronşit, yüksek } \\
\text { ateş }\end{array}$ & $\begin{array}{l}\text { Dekoksiyon / in füzyon } \\
\text { şeklinde hazırlanır ve içilir. }\end{array}$ \\
\hline & & & & & Saç dökülmesi & $\begin{array}{l}\text { Dekoksiyon şeklinde } \\
\text { hazırlanır ve bir hafta saç } \\
\text { yıkanır. }\end{array}$ \\
\hline \multirow{2}{*}{$\begin{array}{l}\text { Carduus nutans L. } \\
\text { subsp. leiophyllus } \\
\text { (Petr.) Stoj. \& Stef. }\end{array}$} & $05 Y 03$ & 5 & Gengelotu & Toprak üstü & Kanser & $\begin{array}{l}\text { Dekoksiyon şeklinde } \\
\text { hazırlanır ve süzülür. Her } \\
\text { gün tok karnına } 1 \text { kez } 1-2 \\
\text { bardak içilir. }\end{array}$ \\
\hline & $08 \mathrm{Z} 02$ & 6 & Eşekdikeni & Çiçek & Mayasıl & $\begin{array}{l}\text { Dekoksiyon ş̧eklinde } \\
\text { hazırlanır ve günde } 1 \text { su } \\
\text { bardağı içilir. }\end{array}$ \\
\hline $\begin{array}{l}\text { Centaurea } \\
\text { solstitialis } \mathrm{L} . \\
\text { subsp. solstitialis }\end{array}$ & 07V04 & 2 & Çakırdikeni & Çiçek & Mayasıl & $\begin{array}{l}\text { Çiçekler dekoksiyon } \\
\text { şeklinde hazırlanır ve içilir. }\end{array}$ \\
\hline
\end{tabular}
bardağ 1 ya da tok karnına her gün 4-5 bardak içilir. ris

Dallar ince ince doğranır, dekoksiyon şeklinde hazırlanır, süzülür. Aç karnına her sabah 1 çay

Mide ülseri and . 


\begin{tabular}{|c|c|c|c|c|c|c|}
\hline $\begin{array}{l}\text { Cirsium arvense } \\
\text { (L.) Scop. subsp. } \\
\text { vestitum }\end{array}$ & 07V03 & 2 & Köygöçürenotu & Yaprak & $\begin{array}{l}\text { Düşme ve ezilmeye } \\
\text { bağll yara }\end{array}$ & $\begin{array}{l}\text { Yaprak iki taş arasında ezilir } \\
\text { ve yaranın üzerine bağlanır. }\end{array}$ \\
\hline
\end{tabular}

\begin{tabular}{|c|c|c|c|c|c|c|}
\hline $\begin{array}{l}\text { Matricaria } \\
\text { chamomilla L. } \\
\text { var. recutita (L.) } \\
\text { Grierson }\end{array}$ & 05W01 & 3 & Papatya & Çiçek & $\begin{array}{l}\text { Öksürük, boğaz ağrısı, } \\
\text { stres ve saç dökülmesi }\end{array}$ & $\begin{array}{l}\text { İnfüzyon şeklinde hazırlanır } \\
\text { ve içilir. }\end{array}$ \\
\hline
\end{tabular}

\begin{tabular}{llllll}
\hline Brassicaceae & & & & \\
\hline $\begin{array}{l}\text { Rapistrum } \\
\text { rugosum (L.) All. }\end{array}$ & $08 Z 03$ & 6 & Hardal & Toprak üstü & $\begin{array}{l}\text { Su ile haşlanarak lapa } \\
\text { kivamında hazırlanır, }\end{array}$ \\
\hline
\end{tabular}

\section{Caprifoliaceae}

\begin{tabular}{|c|c|c|c|c|}
\hline 07V05 & 2 & $\begin{array}{l}\text { Sultanotu/ } \\
\text { Mürver }\end{array}$ & Meyve & Nefes darlığ \\
\hline
\end{tabular}

Olgun meyveleri toplanır ve yenir. Sultanotu, Isirganotu ve Ebegümecinin yaprakları ile Söğüt ağacının dal ve Sambucus nigra L.

05Y04 5 Sultanotu $\quad$ Yaprak
yaprakları dekoksiyon şeklinde hazırlanır. Ağrılı bacaklar 15-20 gün süreyle, sabah-akşam, dayanılabilecek en yüksek sıcaklıkta bu suda bekletilir.

Chenopodiaceae

\begin{tabular}{|c|c|c|c|c|c|c|}
\hline Beta vulgaris L. & 07V06 & 2 & Pancar & Kök & Kansızlık & $\begin{array}{l}\text { Kökleri soyulup dilimlenir } \\
\text { ve kaynatılarak pekmezi } \\
\text { yapılır. }\end{array}$ \\
\hline $\begin{array}{l}\text { Chenopodium } \\
\text { album L. subsp. } \\
\text { album var. album }\end{array}$ & 07U05 & 1 & $\begin{array}{l}\text { Labada/ } \\
\text { Sütlüsirken/ } \\
\text { Yağlıpancar/ } \\
\text { Yağlıhıstır }\end{array}$ & Yaprak & Kabızlık & Çiğ tüketilir. \\
\hline \multicolumn{7}{|l|}{ Cornaceae } \\
\hline Cornus mas L. & 05W02 & 3 & Kizılc1k & Meyve & Kabızlık & $\begin{array}{l}\text { Meyveler dekoksiyon/ } \\
\text { infüzyon şeklinde hazırlanır } \\
\text { ve içilir. }\end{array}$ \\
\hline \multicolumn{7}{|l|}{ Cucurbitaceae } \\
\hline \multirow{3}{*}{$\begin{array}{l}\text { Ecballium } \\
\text { elaterium (L.) A. } \\
\text { Rich. }\end{array}$} & \multirow{3}{*}{ 05Y05 } & \multirow{3}{*}{5} & \multirow{3}{*}{ Kargadüğleği } & Meyve & Bacak ağrısı & $\begin{array}{l}\text { Meyve ve beyaz ispirto bir } \\
\text { şişede } 3-4 \text { gün bekletilir ve } \\
\text { bacaklara sürülür. }\end{array}$ \\
\hline & & & & Kök & Mayasıl & $\begin{array}{l}\text { Kurutulan kök } \\
\text { tanesinin yarısı } \\
\text { büyüklükteki } \\
\text { ayrılır ve günde } 3 \mathrm{kez} \text { tok } \\
\text { olarak yutulur. }\end{array}$ \\
\hline & & & & Meyve & Sinüzit & $\begin{array}{l}\text { Meyvenin içindeki sıvıdan } \\
\text { birkaç damla buruna çekilir. }\end{array}$ \\
\hline \multicolumn{7}{|l|}{ Cupressaceae } \\
\hline $\begin{array}{l}\text { Cupressus } \\
\text { sempervirens L. }\end{array}$ & 05Y06 & 5 & Kobelek & Kozalak & Mide ağrısı ve öksürük & $\begin{array}{c}\text { Kozalaklar dekoksiyon } \\
\text { şeklinde hazırlanır ve aç } \\
\text { veya tok karnına günde 1-2 } \\
\text { bardak tüketilir. }\end{array}$ \\
\hline \multicolumn{7}{|l|}{ Equisetaceae } \\
\hline $\begin{array}{l}\text { Equisetum } \\
\text { ramosissimum } \\
\text { Desf. }\end{array}$ & 05Y07 & 5 & $\begin{array}{l}\text { Eklemotu/ } \\
\text { Mandabıyığı/ } \\
\text { Kilitotu }\end{array}$ & Gövde & Safra taşı & $\begin{array}{l}\text { Gövde dekoksiyon şeklinde } \\
\text { hazırlanır ve tok karnına } \\
\text { günde } 1-2 \text { çay bardağ } \\
\text { tüketilir. }\end{array}$ \\
\hline
\end{tabular}




\section{Fagaceae}

Quercus cerris var. cerris
05Y08

5
Meșe
Dallarin

kabukları

dekoksiyon sonrası anüs yıkanır

\section{Hypericaceae}

\begin{tabular}{|c|c|c|c|c|c|c|}
\hline \multirow{3}{*}{$\begin{array}{l}\text { Hypericum } \\
\text { perforatum } \mathrm{L} .\end{array}$} & 07U06 & 1 & Kantaron çiçeği & Toprak üstü & $\begin{array}{l}\text { Yaralar, mayasıl, } \\
\text { yanıklar }\end{array}$ & $\begin{array}{l}\text { Zeytinyağına konulur ve } \\
\text { karanlık bir yerde } 1 \text { yıl } \\
\text { bekletilir ve gerekli bölgeye } \\
\text { sürülür. } \\
\text { Dekoksiyon şeklinde } \\
\text { hazırlanır ve içilir. }\end{array}$ \\
\hline & 07V07 & 2 & Kantaron çiçeği & Toprak üstü & Mide ağrısı & $\begin{array}{l}\text { Dekoksiyon şeklinde } \\
\text { hazırlanır ve içilir. }\end{array}$ \\
\hline & 05Y09 & 5 & Kantaronotu & Yaprak & $\begin{array}{l}\text { Mide ağrısı, mide } \\
\text { ekşimesi, öksürük ve } \\
\text { soğuk algınlığı }\end{array}$ & 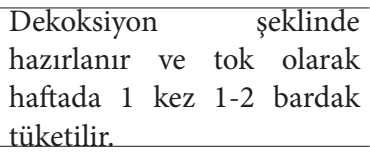 \\
\hline \multicolumn{7}{|l|}{ Juglandaceae } \\
\hline Juglans regia $\mathrm{L}$. & 07U07 & 1 & Ceviz & Yaprak & Bademcik iltihabı & Taze yaprak boğaza bağlanır. \\
\hline \multicolumn{7}{|l|}{ Lamiaceae } \\
\hline $\begin{array}{l}\text { Melissa officinalis } \\
\text { L. subsp. altissima } \\
\text { (Sm.) Arcangeli }\end{array}$ & 07V08 & 2 & Oğulotu & Toprak üstü & Kalp çarpıntısı & $\begin{array}{l}\text { Dekoksiyon şeklinde } \\
\text { hazırlanır ve içilir. }\end{array}$ \\
\hline Mentha sp. & 05W03 & 3 & $\begin{array}{c}\text { Yarpuz/ } \\
\text { Sunanesi/ } \\
\text { Yabannanesi }\end{array}$ & Yaprak & Nezle, grip & $\begin{array}{l}\text { Dekoksiyon şeklinde } \\
\text { hazırlanır ve içilir. }\end{array}$ \\
\hline \multirow[t]{2}{*}{$\begin{array}{l}\text { Mentha } x \text { piperita } \\
\text { L. }\end{array}$} & \multirow[t]{2}{*}{$08 \mathrm{Z} 04$} & \multirow[t]{2}{*}{6} & \multirow[t]{2}{*}{ Nane } & \multirow[t]{2}{*}{ Yaprak } & $\begin{array}{l}\text { Karın ağrısı, soğuk } \\
\text { algınlığı, öksürük, } \\
\text { mide ağrısı ve } \\
\text { bulantıs1, kanser }\end{array}$ & $\begin{array}{l}\text { Dekoksiyon şeklinde } \\
\text { hazırlanır ve günde } 1 \text { su } \\
\text { bardağı içilir. }\end{array}$ \\
\hline & & & & & Obezite & $\begin{array}{l}\text { Dekoksiyon şeklinde } \\
\text { hazırlanır ve günde } 2 \text { su } \\
\text { bardağıicilir. }\end{array}$ \\
\hline $\begin{array}{l}\text { Ocimum } \\
\text { basilicum L. }\end{array}$ & $05 Y 10$ & 5 & Fesleğen & Yaprak & $\begin{array}{l}\text { Arı sokması (ağrı ve } \\
\text { şişmeyi azaltır) }\end{array}$ & $\begin{array}{l}\text { Taze yaprak arının soktuğu } \\
\text { yere konulur ve bir süre } \\
\text { bekletilir. }\end{array}$ \\
\hline \multirow[t]{2}{*}{$\begin{array}{l}\text { Rosmarinus } \\
\text { officinalis L. }\end{array}$} & \multirow[t]{2}{*}{ 07U08 } & \multirow[t]{2}{*}{1} & \multirow[t]{2}{*}{ Biberiye } & \multirow[t]{2}{*}{ Yaprak } & Karaciğer iltihabı & $\begin{array}{l}\text { Iki bardak su ve bir yemek } \\
\text { kaşığı biberiye dekoksiyon } \\
\text { seklinde hazırlanır ve icilir. }\end{array}$ \\
\hline & & & & & Obezite & $\begin{array}{l}\text { Dekoksiyon şeklinde } \\
\text { hazırlanır ve içilir. }\end{array}$ \\
\hline $\begin{array}{l}\text { Thymbra spicata } \\
\text { L. var. spicata }\end{array}$ & 07U09 & 1 & Kekik & Yaprak & Obezite & $\begin{array}{l}\text { Dekoksiyon } \\
\text { hazırlanır ve içilir. }\end{array}$ \\
\hline Thymus sp. & 07U10 & 1 & Tarlakekiği & Yaprak & $\begin{array}{l}\text { Diyabet, bademcik } \\
\text { iltihabı ve obezite }\end{array}$ & $\begin{array}{l}\text { Dekoksiyon şeklinde } \\
\text { hazırlanır ve içilir. }\end{array}$ \\
\hline Thymus sp. & 05W04 & 3 & Yabankekiği & Yaprak & $\begin{array}{l}\text { Düşük tansiyon, mide } \\
\text { ağrısı ve bademcik } \\
\text { iltihabı }\end{array}$ & $\begin{array}{l}\text { Dekoksiyon şeklinde } \\
\text { hazırlanır ve içilir. }\end{array}$ \\
\hline
\end{tabular}




\section{Malvaceae}

\begin{tabular}{|c|c|c|c|c|c|c|}
\hline \multirow{10}{*}{$\begin{array}{l}\text { Malva neglecta } \\
\text { Wallr. }\end{array}$} & \multirow{3}{*}{ 07U11 } & \multirow{3}{*}{1} & \multirow{3}{*}{ Ebegümeci } & \multirow{3}{*}{ Yaprak } & $\begin{array}{l}\text { Göğüs yumuşatıcı ve } \\
\text { guatr }\end{array}$ & \multirow{2}{*}{$\begin{array}{l}\begin{array}{l}\text { Papatya ile } \\
\text { dekoksiyon }\end{array} \\
\text { hazırlanarak içilir. } \\
\text { şeklinde }\end{array}$} \\
\hline & & & & & Mide ağrısı & \\
\hline & & & & & Romatizma & $\begin{array}{l}\text { Haşlanıp ağriyan bölgeye } \\
\text { sarılır. }\end{array}$ \\
\hline & 05W05 & 3 & Ebegümeci & Tüm bitki & $\begin{array}{c}\text { Mide ağrısı ve böbrek } \\
\text { taşı }\end{array}$ & $\begin{array}{l}\text { Dekoksiyon şeklinde } \\
\text { hazırlanır ve maydanoz } \\
\text { suvu ile karıstırılarak icilir. }\end{array}$ \\
\hline & & & & & Göğüs yumuşatıcı & $\begin{array}{l}\text { Dékoksiyon şeklinde } \\
\text { hazırlanır ve aç veya tok } \\
\text { karnına günde } 1-2 \text { bardak } \\
\text { icilir. }\end{array}$ \\
\hline & 05Y11 & 5 & Ebegömeci & Yaprak & & $\begin{array}{l}\text { Sultanotu, Isırganotu ve } \\
\text { Ebegümecinin yaprakları } \\
\text { ile Sögüü ağacının dal ve } \\
\text { yaprakları dekoksiyon }\end{array}$ \\
\hline & & & & & Romatizma & $\begin{array}{l}\text { şeklinde } \text { hazırlanır. Ağrılı } \\
\text { bacaklar } 15-20 \text { gün } \\
\text { süreyle, } \\
\text { dayanıah-akşam, } \\
\text { sıbaklecek en yüksek } \\
\text { sıata bu suda bekletilir. }\end{array}$ \\
\hline & & 6 & Ebegümeci/ & Yaprak & $\begin{array}{c}\text { Göğüs yumuşatıcı, } \\
\text { mide kanseri, karın } \\
\text { ağrısı }\end{array}$ & $\begin{array}{l}\text { Dekoksiyon şeklinde } \\
\text { hazırlanır ve günde } 1 \text { su } \\
\text { bardağ içilir. }\end{array}$ \\
\hline & $08 Z 05$ & & Gelintacı & Toprak üstü & Verem & $\begin{array}{l}\text { Dekoksıyon şeklınde } \\
\text { hazırlanır ve günde } 1-2 \text { su } \\
\text { bardağı içilir. }\end{array}$ \\
\hline & & & & Kök & Mide kanseri & $\begin{array}{l}\text { Dekoksiyon şeklinde } \\
\text { hazırlanır ve günde } 1-2 \text { su } \\
\text { bardağ iccilir. }\end{array}$ \\
\hline Malva sylvestris L. & $05 Y 12$ & 5 & $\begin{array}{l}\text { Ebegümeci/ } \\
\text { Ebegömeci }\end{array}$ & Yaprak ve çiçek & Romatizma & 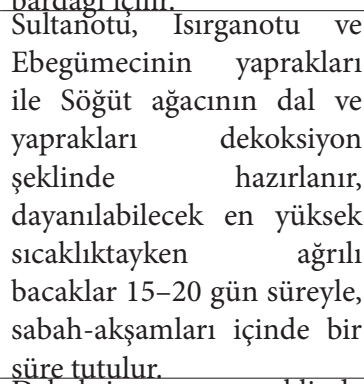 \\
\hline & & & & & Göğüs yumuşatıcı & $\begin{array}{l}\text { Dekoksiyon } \\
\text { hazırlanır ve aç veya tok } \\
\text { karnına günde } 1-2 \text { bardak } \\
\text { içilir. }\end{array}$ \\
\hline Moraceae & & & & & & \\
\hline $\begin{array}{l}\text { Ficus carica L. } \\
\text { subsp. carica }\end{array}$ & 07U12 & 1 & İncir & Meyve & Kabızlık & Çiğ yenir. \\
\hline Morus rubra L. & 07U13 & 1 & $\begin{array}{l}\text { Şamdudu/ } \\
\text { Karadut }\end{array}$ & Meyve & Aft & $\begin{array}{l}\text { Bebeklerin ağı kenarlarına } \\
\text { sürülür. }\end{array}$ \\
\hline Morus alba L. & $08 Z 06$ & 6 & Dut & Yaprak & Mide ağrısı & $\begin{array}{l}\text { Dekoksiyon şeklinde } \\
\text { hazırlanır ve günde } 1 \text { su } \\
\text { bardağı içilir. }\end{array}$ \\
\hline Papaveraceae & & & & & & \\
\hline $\begin{array}{l}\text { Papaver } \\
\text { macrostomum } \\
\text { Boiss. \& Huet ex } \\
\text { Boiss. }\end{array}$ & 05W06 & 3 & Gelincik & Tohum & Bronşit, nefes darlığ 1 & $\begin{array}{l}\text { Tohumlar } \\
\text { karıştırılarak, aç karnına } \\
\text { yenir. }\end{array}$ \\
\hline
\end{tabular}




\section{Plantaginaceae}

\begin{tabular}{|c|c|c|c|c|c|c|}
\hline \multirow{3}{*}{$\begin{array}{l}\text { Plantago major } \mathrm{L} . \\
\text { subsp. intermedia }\end{array}$} & \multirow{3}{*}{ 07U14 } & \multirow{3}{*}{1} & \multirow{3}{*}{$\begin{array}{l}\text { Sinirotu/ } \\
\text { Sinirliot/ } \\
\text { Çıbanotu }\end{array}$} & \multirow{3}{*}{ Yaprak } & $\begin{array}{l}\text { İltihapli yaralar, } \\
\text { burkulmalar }\end{array}$ & $\begin{array}{l}\text { Taze yaprak yaranın üzerine } \\
\text { sabah bağlanır ve } 1 \text { gün } \\
\text { bekletilir. }\end{array}$ \\
\hline & & & & & Diş eti iltihapları & $\begin{array}{l}\text { Dekoksiyon şeklinde } \\
\text { hazırlanır ve gargara yapılır. }\end{array}$ \\
\hline & & & & & Guatr & Taze yaprak boğaza bağlanır. \\
\hline \multicolumn{7}{|l|}{ Poaceae } \\
\hline \multirow{2}{*}{$\begin{array}{l}\text { Cynodon dactylon } \\
\text { (L.) Pers. var. } \\
\text { villosus Regel }\end{array}$} & 07U15 & 1 & Ayrikotu & Rizom & $\begin{array}{c}\text { Mide ağrısı ve böbrek } \\
\text { taşı }\end{array}$ & $\begin{array}{l}\text { Dekoksiyon şeklinde } \\
\text { hazırlanır ve içilir. }\end{array}$ \\
\hline & $05 Y 13$ & 5 & Ayrikotu & Kök & $\begin{array}{l}\text { Böbrek kumu ve damar } \\
\text { sertliği }\end{array}$ & $\begin{array}{l}\text { Dekoksiyon şeklinde } \\
\text { hazırlanır ve her sabah aç } \\
\text { karnına } 1 \text { su bardağı içilir. }\end{array}$ \\
\hline $\begin{array}{l}\text { Cynodon dactylon } \\
\text { (L.) Pers. var. } \\
\text { dactylon Regel }\end{array}$ & $08 \mathrm{Z} 07$ & 6 & Ayrik & Kök & Kireçlenme, romatizma & $\begin{array}{l}\text { Dekoksiyon şeklinde } \\
\text { hazırlanır ve günde } 1 \text { su } \\
\text { bardağ içilir. }\end{array}$ \\
\hline $\begin{array}{l}\text { Hordeum } \\
\text { bulbosum L. }\end{array}$ & 07U16 & 1 & Arpa & Tohum & $\begin{array}{l}\text { Düşme sonucu oluşan } \\
\text { şişlikler }\end{array}$ & $\begin{array}{l}\text { Tohumlar un haline getirilir, } \\
\text { sütle karıştırılır ve şiş yere } \\
\text { bağlanır. }\end{array}$ \\
\hline Zea mays L. & 07V09 & 2 & Misir & Stilus & İdrar yolları iltihabı & $\begin{array}{l}\text { Dekoksiyon şeklinde } \\
\text { hazırlanır ve içilir. }\end{array}$ \\
\hline \multicolumn{7}{|l|}{ Polygonaceae } \\
\hline $\begin{array}{l}\text { Rumex acetosella } \\
\text { L. }\end{array}$ & 05W07 & 3 & Kuzukulağ & Yaprak & Hazımsıllık ve mayasıl & $\begin{array}{l}\text { Dekoksiyon şeklinde } \\
\text { hazırlanır ve içilir. }\end{array}$ \\
\hline \multirow[b]{3}{*}{ Rumex crispus L. } & \multirow[b]{3}{*}{ 07U17 } & \multirow[b]{3}{*}{1} & \multirow[b]{3}{*}{ Evelik/Efelek } & \multirow[b]{3}{*}{ Yaprak } & Kabızlık & Çiğ yenir. \\
\hline & & & & & Bademcik iltihabı & $\begin{array}{l}\text { Taze yaprak haşlanıp } \\
\text { boğazlara sarılır. }\end{array}$ \\
\hline & & & & & Kansızlık & $\begin{array}{l}\text { Dekoksiyon } \\
\text { şeklinde } \\
\text { hazırlanır ve günde } 1 \text { su } \\
\text { bardağ içilir ya da çiğ } \\
\text { olarak yenir. }\end{array}$ \\
\hline \multicolumn{7}{|l|}{ Polypodiaceae } \\
\hline $\begin{array}{l}\text { Polypodium } \\
\text { vulgare L. subsp. } \\
\text { vulgare L. } \\
\text { Portulacaceae }\end{array}$ & 07V01 & 2 & $\begin{array}{l}\text { Taşeğreltisi/ } \\
\text { Eğreltiotu }\end{array}$ & Toprak üstü & Prostat & $\begin{array}{l}\text { Oğulotu ile beraber } \\
\text { dekoksiyon şeklinde } \\
\text { hazırlanır. Yaklaşı bir ay } \\
\text { boyunca her gün içilir. }\end{array}$ \\
\hline $\begin{array}{l}\text { Portulaca oleracea } \\
\text { L. }\end{array}$ & 07U18 & 1 & $\begin{array}{l}\text { Semizotu/ } \\
\text { Semizlik }\end{array}$ & Toprak üstü & Ödem & Çiğ olarak yenir. \\
\hline
\end{tabular}

\section{Ranunculaceae}

\begin{tabular}{|c|c|c|c|c|c|c|}
\hline $\begin{array}{l}\text { Helleborus } \\
\text { orientalis Lam. }\end{array}$ & 07U19 & 1 & Zambak kökü & Kökü & Hayvan halsizlikleri & $\begin{array}{l}\text { Kök bıçakla ufaltılıp } \\
\text { hayvanın kulağına delerek } \\
\text { takılır ve } 12 \text { saat bekletilir. }\end{array}$ \\
\hline \multicolumn{7}{|l|}{ Rhamnaceae } \\
\hline \multirow{2}{*}{$\begin{array}{l}\text { Paliurus spina- } \\
\text { christi Miller }\end{array}$} & 07U20 & 1 & Dikenli çalı & Meyve & Böbrek taşı & $\begin{array}{l}\text { Dekoksiyon şeklinde } \\
\text { hazırlanır ve her gün içilir. }\end{array}$ \\
\hline & $08 Z 08$ & 6 & Karaçalı & Çiçek & Böbrek taşı & $\begin{array}{l}\text { Dekoksiyon şeklinde } \\
\text { hazırlanır ve günde } 1 \text { su } \\
\text { bardağı içilir. }\end{array}$ \\
\hline
\end{tabular}


Rosaceae

\begin{tabular}{|c|c|c|c|c|c|c|}
\hline $\begin{array}{l}\text { Cerasus avium } \\
\text { (L.) Moench }\end{array}$ & 07U21 & 1 & Kiraz & Meyve sap1 & Böbrek taşı & $\begin{array}{l}\text { Dekoksiyon şeklinde } \\
\text { hazırlanır ve iyileşinceye } \\
\text { kadar her gün içilir. }\end{array}$ \\
\hline $\begin{array}{l}\text { Crataegus } \\
\text { monogyna Jacq. } \\
\text { subsp. monogyna }\end{array}$ & $05 Y 14$ & 5 & Yemişken & Yaprak & Kalp yetmezliği & $\begin{array}{l}\text { Dekoksiyon şeklinde } \\
\text { hazırlanır ve içilir. }\end{array}$ \\
\hline & 07U22 & 1 & Ayva & Yaprak & Öksürük & $\begin{array}{l}\text { Dekoksiyon şeklinde } \\
\text { hazırlanır ve içilir. }\end{array}$ \\
\hline
\end{tabular}

Cydonia oblonga Miller

05Y15 5 Ayva ağacı $\begin{gathered}\text { Meyve ve } \\ \text { yaprak }\end{gathered} \quad$ Safra taşı

Dekoksiyon şeklinde hazırlanarak, aç veya tok karnına günde yarım veya bir çay bardağ

Güvem, Ahlat, Kuşburnu, ve Nar meyveleri ile beraber bidonda 1 hafta bekletildikten sonra içilir.

$\begin{array}{lllll}08 Z 09 & 6 & \text { Ayva } & \text { Yaprak } & \text { Grip }\end{array}$

İnfüzyon şeklinde hazırlanır ve günde 1 su bardağı içilir.

Prunus divaricata Ledeb. subsp. divaricata

$05 Y 16$

5

Güvem

Meyve
Güvem, Ahlat, Kuşburnu, ve Nar meyveleri ile beraber bidonda 1 hafta bekletildikten sonra aç veya tok karnına her gün 2-3 bardak içilir.

\begin{tabular}{|c|c|c|c|c|c|c|}
\hline Prunus spinosa L. & $08 Z 10$ & 6 & Güvem (Diranka) & Meyve & $\begin{array}{l}\text { Kanser, mide ülseri, } \\
\text { diyabet, grip, öksürük }\end{array}$ & $\begin{array}{l}\text { Dekoksiyon şeklinde } \\
\text { hazırlanır ve günde } 1 \text { su } \\
\text { bardağı içilir. }\end{array}$ \\
\hline
\end{tabular}

\section{Pyrus}

amygdaliformis

Vill. var.

amygdaliformis

05Y17 $5 \quad \begin{array}{ccc}\text { Ahlat/ } & \text { Meyve/ } \\ \text { Yabaniahlat } & \text { Ççek } & \text { Safra taşı }\end{array}$

Güvem, Ahlat, Kuşburnu, ve Nar ile beraber bidonda 1 hafta bekletildikten sonra içilmektedir. Her gün aç veya tok karnına 2-3 bardak tüketilmektedir.

\begin{tabular}{|c|c|c|c|c|c|c|}
\hline $\begin{array}{l}\text { Pyrus elaeagnifolia } \\
\text { Palas subsp. } \\
\text { elaeagnifolia }\end{array}$ & $08 Z 11$ & 6 & Yabanahladı & Meyve & $\begin{array}{l}\text { Yüksek kolesterol, } \\
\text { diyabet }\end{array}$ & $\begin{array}{l}\text { Meyveler bir kap suda 15-20 } \\
\text { gün bekletilir ve günde 1-2 } \\
\text { su bardağ1 içilir. }\end{array}$ \\
\hline \multirow{5}{*}{ Rosa canina $\mathrm{L}$. } & \multirow{2}{*}{$07 \mathrm{U} 23$} & \multirow[t]{2}{*}{1} & \multirow[t]{2}{*}{ Kuşburnu } & \multirow{2}{*}{ Meyve, kök } & Mayasıl & $\begin{array}{l}\text { Dekoksiyon şeklinde } \\
\text { hazırlanır ve içilir. }\end{array}$ \\
\hline & & & & & Mayasıl & Pekmezi hazırlanır ve yenir. \\
\hline & $07 \mathrm{~V} 10$ & 2 & Kuşburnu & Meyve & Mide ağrısı & $\begin{array}{l}\text { Marmelat şeklinde } \\
\text { hazırlanır ve aç karnına her } \\
\text { sabah yenir. }\end{array}$ \\
\hline & $05 \mathrm{Y} 18$ & 5 & $\begin{array}{l}\text { Kuşburnu/ } \\
\text { Yabangülü }\end{array}$ & Meyve, çiçek & Düşük vücut direnci & $\begin{array}{l}\text { Dekoksiyon şeklinde } \\
\text { hazırlanır ve kışın aç veya } \\
\text { tok karnına haftada } 2-3 \mathrm{kez} \text {, } \\
\text { 1-2 bardak tüketilir. }\end{array}$ \\
\hline & $08 Z 12$ & 6 & Kuşburnu & Meyve & $\begin{array}{l}\text { Kanser, öksürük, grip, } \\
\text { karın ağrısı }\end{array}$ & $\begin{array}{l}\text { Dekoksiyon şeklinde } \\
\text { hazırlanır ve günde } 1 \text { su } \\
\text { bardağı içilir. }\end{array}$ \\
\hline
\end{tabular}




\begin{tabular}{|c|c|c|c|c|c|c|}
\hline \multirow{3}{*}{$\begin{array}{l}\text { Rubus sanctus } \\
\text { Schreber }\end{array}$} & \multirow{2}{*}{$\begin{array}{l}\text { 07U24 } \\
\text { 05W08 }\end{array}$} & \multirow{2}{*}{$\begin{array}{l}1 \\
3 \\
\end{array}$} & \multirow{2}{*}{$\begin{array}{l}\text { Böğürtlen } \\
\text { Ahududu/ } \\
\text { Böğürtlen }\end{array}$} & \multirow{2}{*}{$\begin{array}{c}\text { Meyve, kök } \\
\text { Meyve }\end{array}$} & \multirow{2}{*}{$\begin{array}{l}\text { Astım, egzama } \\
\text { Yüksek tansiyon }\end{array}$} & \multirow{2}{*}{$\begin{array}{l}\text { Dekoksiyon şeklinde } \\
\text { hazırlanır ve her gün içilir. } \\
\text { Çiğ ya da şekerle } \\
\text { karıştırılarak tüketilir. }\end{array}$} \\
\hline & & & & & & \\
\hline & $05 Y 19$ & 5 & $\begin{array}{l}\text { Karamık/ } \\
\text { Böğürtlen }\end{array}$ & Meyve, kök & Kabızlık & $\begin{array}{l}\text { Dekoksiyon şeklinde } \\
\text { hazırlanır ve tok veya aç } \\
\text { karnına ayda } 1-2 \text { kez } 1-2 \\
\text { bardak içilir. }\end{array}$ \\
\hline $\begin{array}{l}\text { Rubus discolor } \\
\text { Weihe \& Nees }\end{array}$ & $08 Z 13$ & 6 & $\begin{array}{l}\text { Böğürtlen } \\
\text { (Kapina) }\end{array}$ & Meyve & Kanser, baş ağrısı & $\begin{array}{l}\text { Dekoksiyon şeklinde } \\
\text { hazırlanır, günde } 1 \text { su } \\
\text { bardağı içilir ya da çiğ yenir. }\end{array}$ \\
\hline \multicolumn{7}{|l|}{ Rubiaceae } \\
\hline $\begin{array}{l}\text { Galium } \\
\text { rotundifolium } \mathrm{L} .\end{array}$ & $08 Z 14$ & 6 & Hidrallezçiçeği & Tüm bitki & Saç dökülmesi & $\begin{array}{l}\text { Dekoksiyon şeklinde } \\
\text { hazırlanır, haftada } 1 \text { kez } \\
\text { saçlar yıkanır. }\end{array}$ \\
\hline \multicolumn{7}{|l|}{ Salicaceae } \\
\hline \multirow[b]{2}{*}{ Salix sp. } & \multirow[b]{2}{*}{$05 Y 20$} & \multirow[b]{2}{*}{5} & \multirow[b]{2}{*}{ Söğüt } & \multirow[b]{2}{*}{$\begin{array}{c}\text { Dal ve } \\
\text { yapraklar }\end{array}$} & Diyabet & $\begin{array}{l}\text { Dekoksiyon şeklinde } \\
\text { hazırlanır ve aç veya tok } \\
\text { karnına bir bardak tüketilir. }\end{array}$ \\
\hline & & & & & Romatizma & $\begin{array}{l}\text { Sultanotu, Isırganotu ve } \\
\text { Ebegümecinin yapraklar } \\
\text { ile Söğü ağacının dal ve } \\
\text { yaprakları dekoksiyon } \\
\text { şeklinde hazırlanır. Ağrılı } \\
\text { bacaklar 15-20 gün } \\
\text { süreyle, sabah-akşam, } \\
\text { dayanılabilecek en yüksek } \\
\text { sicaklıkta bu suda bekletilir. }\end{array}$ \\
\hline Salix alba L. & $08 Z 15$ & 6 & Yabansöğüdü & Kabuk & Sinüzit & $\begin{array}{l}\text { Dekoksiyon şeklinde } \\
\text { hazırlanır, günde } 1 \text { su } \\
\text { bardağı içilir. }\end{array}$ \\
\hline \multicolumn{7}{|l|}{ Scrophulariaceae } \\
\hline $\begin{array}{l}\text { Verbascum } \\
\text { cherianthifolium } \\
\text { var. } \\
\text { cherianthifolium } \\
\text { Tiliaceae }\end{array}$ & 07U25 & 1 & Sığırkuyruğu & Toprak üstü & $\begin{array}{l}\text { Hayvanlarda soğuk } \\
\text { algınlığ } 1\end{array}$ & $\begin{array}{l}\text { Dekoksiyon şeklinde } \\
\text { hazırlanır ve hayvanlara } \\
\text { içirilir. }\end{array}$ \\
\hline \multirow{2}{*}{$\begin{array}{l}\text { Tilia argentea } \\
\text { Desf. ex DC. }\end{array}$} & 05W09 & 3 & Ihlamur & Çiçek & Soğuk algınlığı, grip & $\begin{array}{l}\text { Dekoksiyon / infü zyon } \\
\text { şeklinde hazırlanır ve içilir. }\end{array}$ \\
\hline & $08 Z 16$ & 6 & Ihlamur & Toprak üstü & $\begin{array}{c}\text { Soğuk algınlığı, karın } \\
\text { ağrısı }\end{array}$ & $\begin{array}{l}\text { Dekoksiyon şeklinde } \\
\text { hazırlanır ve günde } 2 \text { su } \\
\text { bardağı içilir. }\end{array}$ \\
\hline $\begin{array}{l}\text { Tilia cordata } \\
\text { Miller }\end{array}$ & 07V11 & 2 & Ihlamur & $\begin{array}{l}\text { Yaprak ve } \\
\text { meyve }\end{array}$ & Soğuk algınlığı & $\begin{array}{l}\text { Dekoksiyon şeklinde } \\
\text { hazırlanır, içine tarçın ve } \\
\text { karanfil eklenerek içilir. }\end{array}$ \\
\hline
\end{tabular}




\section{Urticaceae}

Urtica dioica $\mathrm{L}$.

\begin{tabular}{|c|c|c|c|c|c|}
\hline \multirow{4}{*}{ 07U26 } & \multirow{4}{*}{1} & \multirow{4}{*}{$\begin{array}{l}\text { Isirgan/ } \\
\text { Isirganotu }\end{array}$} & $\begin{array}{l}\text { Tohum ve } \\
\text { yaprak }\end{array}$ & $\begin{array}{l}\text { Kanser, idrar yolları } \\
\text { iltihabı }\end{array}$ & $\begin{array}{l}\text { Balla karıştırılarak yenir } \\
\text { ya da dekoksiyon şeklinde } \\
\text { hazırlanarak içilir. }\end{array}$ \\
\hline & & & Yaprak & Saç dökülmesi & \begin{tabular}{llr} 
Dekoksiyon & \multicolumn{2}{r}{ şeklinde } \\
hazırlanarak & saça \\
yapılır & &
\end{tabular} \\
\hline & & & Yaprak & $\begin{array}{l}\text { Mide ülseri ve idrar } \\
\text { yolları iltihabı }\end{array}$ & $\begin{array}{l}\text { Isırgantu, papatya ve } \\
\text { kekikle beraber dekoksiyon } \\
\text { șeklinde hazırlanır, her gün } \\
\text { bir çay bardağı içilir. }\end{array}$ \\
\hline & & & Yaprak & Romatizma & $\begin{array}{l}\text { Taze yaprak haşlanıp ezilir } \\
\text { ve dize uygulanır. }\end{array}$ \\
\hline \multirow{4}{*}{$05 \mathrm{~W} 10$} & \multirow{4}{*}{3} & \multirow{4}{*}{ Isırganotu } & Tohum & Kanser & $\begin{array}{l}\text { Dekoksiyon şeklinde } \\
\text { hazırlanarak icilir. }\end{array}$ \\
\hline & & & Yaprak & Romatizma & $\begin{array}{l}\text { Lapa yapılarak veya çiğ } \\
\text { olarak ağrıyan yerlere } \\
\text { uygulanır. }\end{array}$ \\
\hline & & & Yaprak & $\begin{array}{l}\text { Nezle, grip, diyabet, } \\
\text { öksürük }\end{array}$ & $\begin{array}{l}\text { Dekoksiyon şeklinde } \\
\text { hazırlanır ve içilir. }\end{array}$ \\
\hline & & & Yaprak & Sivilce & $\begin{array}{l}\text { Dekoksiyon şeklinde } \\
\text { hazırlanır ve vüz yıkanır }\end{array}$ \\
\hline \multirow{10}{*}{$05 Y 21$} & \multirow{10}{*}{5} & \multirow{10}{*}{ Isırganotu } & \multirow{10}{*}{ Yaprak } & Romatizma & $\begin{array}{l}\text { Dekoksiyon şeklinde } \\
\text { hazırlanır, aç veya tok } \\
\text { karnına sabah, öğle, akşam } \\
1-2 \text { bardak içilir. }\end{array}$ \\
\hline & & & & Böbrek yetmezliği & $\begin{array}{l}\text { Dekoksiyon şeklinde } \\
\text { hazırlanır ve aç karnına her } \\
\text { sabah 1-2 bardak tüketilir. }\end{array}$ \\
\hline & & & & Düşük vücut direnci & $\begin{array}{l}\text { Dekoksiyon şeklinde } \\
\text { hazırlanır ve aç veya tok } \\
\text { karnına haftada } 1-2 \text { kez, } 1-2 \\
\text { bardak 1-2 bardakicilir }\end{array}$ \\
\hline & & & & Kanser & $\begin{array}{l}\text { Dekoksiyon şeklinde } \\
\text { hazırlanır ve aç veya tok } \\
\text { karnına her sabah } 1-2 \\
\text { bardakiçilir. }\end{array}$ \\
\hline & & & & Mayasıl, mide ekşimesi & $\begin{array}{l}\text { Dekoksiyon şeklinde } \\
\text { hazırlanır ve aç karnına her } \\
\text { sabah 1-2 bardak içilir. }\end{array}$ \\
\hline & & & & İdrar yollarr iltihabı & $\begin{array}{l}\text { Dekoksiyon şeklinde } \\
\text { hazırlanır ve aç veya tok } \\
\text { karnına her gün 3-4 bardak }\end{array}$ \\
\hline & & & & Romatizma & $\begin{array}{l}\text { Iclür. } \\
\text { Taze bitki doğrudan bacağa } \\
\text { konulur ya da sultan otu, } \\
\text { Isırganotu ve Ebegümecinin } \\
\text { yaprakları ile Söğ̈ü ağacinın } \\
\text { dal ve yaprakları birlikte } \\
\text { dekoksiyon şeklinde }\end{array}$ \\
\hline & & & & & $\begin{array}{l}\text { hazırlanır. } 15-20 \text { gün } \\
\text { süreyle, sabah-akşam, ağrılı } \\
\text { bacaklar dayanılabilecek } \\
\text { en yüksek sıcaklıkta bu sıvı } \\
\text { içinde bekletilir. }\end{array}$ \\
\hline & & & & Saç dökülmesi & $\begin{array}{l}\text { Dekoksiyon şeklinde } \\
\text { hazırlanır ve şaçlar yıkanır. }\end{array}$ \\
\hline & & & & Romatizma & $\begin{array}{l}\text { Ateşte kavurup bir beze } \\
\text { konup sıcak olarak ağriyan } \\
\text { yere uvgulanır. }\end{array}$ \\
\hline
\end{tabular}




\begin{tabular}{|c|c|c|c|c|c|c|}
\hline & & \multirow{6}{*}{6} & & Toprak üstü & $\begin{array}{l}\text { Romatizma, astım, } \\
\text { idrar yolları iltihabı, } \\
\text { ödem, böbrek ağrısı, } \\
\text { kanser }\end{array}$ & $\begin{array}{l}\text { Dekoksiyon şeklinde } \\
\text { hazırlanır ve günde } 1 \text { su } \\
\text { bardağı içilir. }\end{array}$ \\
\hline \multirow{5}{*}{ Urtica urens L. } & \multirow{5}{*}{$08 \mathrm{Z} 17$} & & \multirow{5}{*}{ Isırganotu } & Toprak üstü & Romatizma & $\begin{array}{l}\text { Lapa şeklinde hazırlanır ve } \\
\text { soğuyunca ağrıyan bölgeye } \\
\text { uygulanır. }\end{array}$ \\
\hline & & & & \multirow{2}{*}{ Tohum } & $\begin{array}{l}\text { Menapoz, kanser, grip, } \\
\text { karın ağrısı }\end{array}$ & $\begin{array}{l}\text { Dekoksiyon şeklinde } \\
\text { hazırlanır ve günde } 1 \text { su } \\
\text { bardağ } 1 \text { içilir. }\end{array}$ \\
\hline & & & & & Kanser & $\begin{array}{l}\text { Balla karıştırılır ve günde } 1 \\
\text { kere, sabah aç karnına yenir. }\end{array}$ \\
\hline & & & & Yaprak & Karın ağrısı & $\begin{array}{l}\text { İnfüzyon şeklinde hazırlanır } \\
\text { ve günde } 1 \text { su bardağı içilir. }\end{array}$ \\
\hline & & & & Çiçek & Yanık & $\begin{array}{l}\text { Zeytinyağı ile karıştırılarak } \\
\text { merhem hazırlanır ve } \\
\text { sabah-akşam yanık bölgeye } \\
\text { sürülür. }\end{array}$ \\
\hline \multicolumn{7}{|l|}{ Vitaceae } \\
\hline $\begin{array}{l}\text { Vitis sylvestris } \\
\text { Gmelin }\end{array}$ & 07U27 & 1 & Asma & Yaprak & $\begin{array}{l}\text { Sütten kesilmeyi } \\
\text { kolaylaştırma }\end{array}$ & Göğüs üzerine konur. \\
\hline \multicolumn{7}{|l|}{ Zygophyllaceae } \\
\hline \multirow{4}{*}{$\begin{array}{l}\text { Tribulus terrestris } \\
\mathrm{L} .\end{array}$} & \multirow{3}{*}{ 07U28 } & \multirow{3}{*}{1} & \multirow{3}{*}{ Demirdikeni } & Toprak üstü & Damar tıkanıklığı & $\begin{array}{l}\text { Dekoksiyon şeklinde } \\
\text { hazırlanır ve içilir. }\end{array}$ \\
\hline & & & & & & \\
\hline & & & & $\begin{array}{l}\text { Diken, } \\
\text { yaprak }\end{array}$ & Diyabet & $\begin{array}{l}\text { Dekoksiyon şeklinde } \\
\text { hazırlanır ve içilir. }\end{array}$ \\
\hline & $05 Y 22$ & 5 & $\begin{array}{l}\text { Kalkitanotu/ } \\
\text { Çobankalkıtan }\end{array}$ & Yaprak & Romatizma & $\begin{array}{l}\text { Dekoksiyon şeklinde } \\
\text { hazırlanır ve aç veya tok } \\
\text { karnına günde } 1 \text { bardak } \\
\text { içilir. }\end{array}$ \\
\hline
\end{tabular}

*1. Bilecik/Aşağıköy 2. Bilecik/Pazaryeri/Büyük Elmalı 3. Bursa/Merkez 4. Edirne/Keşan 5. Edirne/Keşan/Kozköy 6. Edirne-İpsala 
Tablo 6. Belirtilen hastalıkların farmakolojik etkinliklerine göre gruplandırılması.

\begin{tabular}{|c|c|}
\hline Hastalık Tipleri & Semptomlar \\
\hline Dermatolojik Hastalıklar & $\begin{array}{l}\text { Saç dökülmesi, yara (sulu yara, iltihaplı yara, düşme ve ezilmeye bağlı yara vb.), } \\
\text { egzama, yanık, sivilce }\end{array}$ \\
\hline Kardiyovasküler Hastalıklar & $\begin{array}{l}\text { Tansiyon, yüksek kolesterol, kalp-damar hastalıkları (damar tıkanıklığı, damar } \\
\text { sertliği, kalp çarpıntısı, kalp yetmezliği vb.) }\end{array}$ \\
\hline Gastro-İntestinal Hastalıklar & $\begin{array}{l}\text { Kabızlık, mide ülseri, karın ağrısı, hazımsızlık, mide bulantısı, mayasıl, mide ağrısı, } \\
\text { mide ekşimesi, safra taşı, karaciğer iltihabı }\end{array}$ \\
\hline Solunum Sistemi ve Gögüs Hastalıkları & $\begin{array}{l}\text { Astım, bronşit, öksürük, boğaz ağrısı, nefes darlığı, sinüzit, soğuk algınlığı, badem- } \\
\text { cik iltihabı, nezle, grip, göğüs yumuşatıcı, verem }\end{array}$ \\
\hline Endokrin Sistemi Hastalıkları & Diyabet, obezite, sütten kesilmeyi kolaylaştırma, guatr \\
\hline Yangılı Hastalıklar & Romatizma, kireçlenme, bacak ağrısı \\
\hline $\begin{array}{l}\text { Hematopoetik, İmmün Sistem Hastalıkları ve } \\
\text { Kanser }\end{array}$ & Kanser, kansızlık, düşük vücut direnci, yüksek ateş \\
\hline Üriner Sistem Hastalıkları & $\begin{array}{l}\text { Prostat, ödem, idrar yolları iltihabı, böbrek yetmezliği, böbrek ağrısı, böbrek kumu, } \\
\text { böbrek taşı }\end{array}$ \\
\hline Jinekolojik Hastalıklar & Menopoz \\
\hline Ağız Hastalıkları & Ağız yaraları, aft, diş eti iltihabı \\
\hline İskelet ve Kas Sistemi Hastalıkları & Burkulma, düşme sonucu oluşan şişlik \\
\hline Psikiyatrik Hastalıklar & Stres \\
\hline Nörolojik Hastalıklar & Baş ağrısı \\
\hline Hayvan Hastalıkları & Soğuk algınlığı, halsizlik \\
\hline Diğer Hastalıklar & Ar1 sokması \\
\hline
\end{tabular}

Kullanım amacı olarak, yapılan diğer çalışmalarla benzerlik gösteren taksonlar arasında; Carduus nutans L. toprak üstü kısımları kanser tedavisinde; Cerasus avium (L.) Moench meyve sapı böbrek taşı tedavisinde; Chenopodium album L. subsp. album var. album yaprakları kabızlık tedavisinde; Cornus mas L. meyvesi kabızlık tedavisinde; Cotinus coggyria Scop. dalları mide ülseri ve ağız yaraları tedavisinde, yaprakları ise sulu yara tedavisinde; Crataegus monogyna Jacq. yaprakları kalp yetmezliği tedavisinde; Cydonia oblonga Miller yaprakları öksürük tedavisinde; Cynodon dactylon (L.) Pers. rizomu böbrek kumu ve romatizma tedavisinde; Ecballium elaterium (L.) A. Rich. meyvesi bacak ağrısı, meyvesinin suyu sinüzit tedavisinde, kökü ise mayasıl tedavisinde; Helleborus orientalis Lam. kökleri hayvan hastalıkları tedavisinde; Hypericum perforatum L. toprak üstü kısımları mayasıl, mide ağrısı, öksürük, yara ve yanık tedavisinde; Malva neglecta Wallr. yaprakları mide ağrısı ve mide kanseri tedavisinde; Matricaria chamomilla L. var. recutita (L.) Grierson çiçekleri öksürük ve boğaz ağrısı tedavisinde; Mentha $x$ piperita L. yaprakları karın ağrısı ve soğuk algınlığı tedavisinde; Paliurus spina-christi Miller meyvesi böbrek taşı tedavisinde; Petroselinum crispum (Miller) A. W. Hill toprak üstü kısımları idrar yolları iltihabı ve böbrek kumu tedavisinde; Plantago major L. subsp. intermedia yaprakları iltihaplı yara tedavisinde; Portulaca oleracea L. toprak üstü kısımları ödem söktürücü olarak; Prunus spinosa L. meyvesi diyabet tedavisinde; Rosmarinus officinalis L. yaprakları obezite tedavisinde; Rosa canina L. meyvesi ve kökü mayasıl tedavisinde, meyvesi öksürük, karın ağrısı ve grip tedavisinde; Urtica dioica L. yaprakları romatizma, saç dökülmesi, diyabet, mayasıl, kanser ve idrar yolları iltihabı tedavisinde, tohumu ise kanser tedavisinde; Urtica urens L. toprak üstü kısımları böbrek ağrısı, kanser, karın ağrısı ve romatizma tedavisinde kullanılmaktadır [3, 4, 6-8, 10-19, 21-23].

Diğer çalışmalardan farklı olarak ise; Achillea setacea Waldst. et Kit. toprak üstü kısımları egzama tedavisinde; Beta vulgaris L. kökleri kansızlık tedavisinde; Carduus nutans L. çiçekleri ve Centaurea solstitialis L. subsp. solstitialis çiçekleri mayasıl tedavisinde; Coriandrum sativum $L$. tohumu 
tansiyon düşürücü olarak; Cydonia oblonga Miller meyve ve yaprakları safra taşı tedavisinde; Ficus carica L. subsp. carica meyvesi kabizlık tedavisinde; Hordeum bulbosum L. tohumları düşme sonucu oluşan şişliklerde; Hypericum perforatum L. yaprakları soğuk algınlığı tedavisinde; Juglans regia L. yaprakları bademcik iltihabı tedavisinde; Malva neglecta Wallr. yaprakları göğüs yumuşatıcı olarak, ayrıca guatr, romatizma, böbrek taşı ve verem tedavisinde, kökleri ise mide kanseri tedavisinde; Malva sylvestris L. yaprak ve çiçekleri göğüs yumuşatıcı olarak ve romatizma tedavisinde; Mentha x piperita L. yaprakları obezite ve kanser tedavisinde; Morus alba L. yaprakları mide ağrısı tedavisinde; Papaver macrostomum Boiss. \& Huet ex Boiss. tohumları bronşit ve nefes darlığı tedavisinde; Plantago major L. subsp. intermedia yaprakları burkulma, diş eti iltihabı, guatr tedavisinde; Pyrus elaeagnifolia Palas subsp. elaeagnifolia meyvesi yüksek kolestrol ve diyabet tedavisinde; Rosa canina L. meyvesi vücut direncini kuvvetlendirmede ve kanser tedavisinde; Rosmarinus officinalis L. yaprakları karaciğer iltihabı tedavisinde; Rubus sanctus Schreber meyvesi ve kökü astım, egzama ve kabızlık tedavisinde; Sambucus nigra L. meyveleri

Folk Medicine in Selected Towns of the Marmara Subregion (Turkey)

\section{ABSTRACT}

In this study, 263 volunteers residing in the districts of Bilecik-Aşağıköy, Bilecik-Pazaryeri-Büyük Elmalı, Bursa-City Center, Edirne-Keşan-Kozköy, Edirne-Keşan and Edirneİpsala participated into the research by using the face-to-face oral interview technique and the required information for the research was collected with the help of a questionary. In the light of the data taken from the survey, parts of the plants that are used as household remedy, aim of the usage and pattern of the preparation (decoction, infusion, poultice, ointment etc.) were

\section{KAYNAKLAR}

[1] Yeşilada E, Sezik E. Phytotherapie in der Türkei. Z Phytother 1998; 19:132-8.

[2] Sezik E, Tabata M, Yeşilada E, Honda G, Goto K, Ikeshiro Y. Traditional medicine in Turkey I. Folk medicine in North-East Anatolia. J Etnopharmacol 1991; 35:191-6.

[3] Sezik E, Zor M, Yeşilada E. Traditional medicine in Turkey II: Folk medicine in Kastamonu. Int J Pharmacogn 1992; 30:233-9.

[4] Yeşilada E, Honda G, Sezik E, Tabata M, Goto K, Ikeshiro Y. Traditional medicine in Turkey. IV. Folk medicine in Mediterranean subdivision. J Ethnopharmacol 1993; 39:31-8.

[5] Tabata M, Sezik E, Honda G, Yesilada E, Fukui H, Goto K, Ikeshiro Y. Traditional medicine in Turkey. III. Folk medicine nefes darlığı tedavisinde; Thymbra spicata L. var. spicata yaprakları obezite tedavisinde; Urtica dioica L. yaprakları mide ülseri, nezle, öksürük, grip, sivilce, böbrek yetmezliği ve mide ekşimesi tedavisinde, ayrıca vücut direncini kuvvetlendirmede; Urtica urens L. tohumları menapoz ve grip tedavisinde, çiçekleri yanık tedavisinde, toprak üstü kısımları idrar yolları iltihabı ve astım tedavisinde, ayrıca ödem söktürücü olarak; Zea mays L. stilüsü idrar yolları iltihabı tedavisinde; Tribulus terrestris L. toprak üstü kısımları damar tıkanıklığı tedavisinde kullanılmaktadır.

Sonuç olarak, herbaryum materyali haline getirilen bitki örneklerinden 33 familyaya ait 68 taksonun halk ilacı olarak 187 kullanımı tespit edilmiştir. Bu taksonların 4’ü cins düzeyinde, geri kalanı ise tür, alttür veya varyete düzeyinde tanımlanmış olup \%14,7'si Rosaceae (10 takson), \%11,8'i Lamiaceae (8 takson), \%10,3'ü Asteraceae (7 takson) ve \%5,9'u Poaceae (4 takson) familyalarına aittir. Tedavi amaçıı kullanımların özellikle gastro-intestinal sistem, solunum sistemi ve gögüs hastalıkları, üriner sistem, kanser, hematopoetik ve immün sistem hastalıklarına karşı olduğu görülmektedir.

documented inquisitively. All collected plant materials have been identified and deposited at the Herbarium of Faculty of Education of Hacettepe University (HEF). In this study, 68 taxa belonging to 33 families were found to be used as household remedy. It was observed that the majority of these plants belonged to Rosaceae (10 taxa), Lamiaceae (8 taxa), Asteraceae (7 taxa) and Poaceae (4 taxa) families. Gastrointestinal system (46 remedies; $24,6 \%$ ), respiratory system and chest diseases (41 remedies; 21,9\%), urinary system (18 remedies; 9,6\%), hemapoietic, immune system and cancer (18 remedies; 9,6\%) remain most among 187 uses were documented as household remedy.

Keywords: Folk medicine, Bilecik, Bursa, Edirne, Turkey. in East Anatolia; Van and Bitlis provinces. Int J Pharmacogn 1994; 32:3-12.

[6] Fujita T, Sezik E, Tabata M, Yeşilada E, Honda G, TakedaY, Tanaka T, Takaishi Y. Traditional medicine in Turkey VII. Folk medicine in middle and west Black Sea Regions. Economic Botany 1995; 49:406-422.

[7] Yeşilada E, Honda G, Sezik E, Tabata M, Fujita T, Tanaka T, Takeda Y, Takaishi Y. Traditional medicine in Turkey V. Folk medicine in the inner Taurus mountains. J Ethnopharmacol 1995; 46:133-52.

[8] Honda G, Yeşilada E, Tabata M, Sezik E, Fujita T, Takeda Y, Tanaka T, Takaishi Y. Traditional medicine in Turkey. VI. Folk medicine in West Anatolia. J Ethnopharmacol 1996; 53:75-87.

[9] Sezik E, Yeşilada E, Tabata M, Honda G, Takaishi Y, Fujita T, 
Tanaka T, Takeda Y. Traditional medicine in Turkey VIII. Folk medicine east Anatolia. Econ Bot 1997; 51:195-211.

[10] Yeșilada E, Sezik E, Honda G, Takaishi Y, Takeda Y, Tanaka T. Traditional medicine in Turkey IX. Folk medicine in northwest Anatolia. J Ethnopharmacol 1999; 64:195-210.

[11] Sezik E, Yeşilada E, Honda G, Takaishi Y, Takeda Y, Tanaka T. Traditional medicine in Turkey X. Folk medicine in Central Anatolia. J Etnopharmacol 2001; 75:95-115.

[12] Kültür Ş. Medicinal plants used in Kırklareli Province (Turkey). J Ethnopharmacol 2007; 111:341-64.

[13] Özüdoğru B, Akaydın G, Erik S, Yeşilada E. Inferences from an ethnobotanical field expedition in the selected locations of Sivas and Yozgat provinces (Turkey). J Ethnopharmacol 2011; 137:85-98.

[14] Kaval İ, Behçet L, Çakılcıoğlu U. Ethnobotanical study on medicinal plants in Geçitli and its surrounding (HakkariTurkey). J Ethnopharmacol 2014; 155:171-84.

[15] Bulut G. Folk medicinal plants of Silivri (İstanbul, Turkey). Marmara Pharm J 2011; 15: 25-9.

[16] Tuzlacı E, Alparslan DF. Turkish folk medicinal plants, part V: Babaeski (Kırklareli). J Fac Pharm Istanbul Univ 2007; 39:1123.

[17] Koçyiğit M, Özhatay N. Wild plants used as medicinal purpose in Yalova (Northwest Turkey). Turk J Pharm Sci 2006; 3:91103.

[18] Tuzlacı E, Alparslan İşbilen DF, Bulut G. Turkish folk medicinal plants, VIII: Lalapaşa (Edirne). Marmara Pharma J 2010; 14:47-52.

[19] Saçlı S, Akalın E. Preliminary ethnobotanical study from Kazdağı (Balıkesir/Çanakkale) I: Uses and vernacular names. J Fac Pharm Istanbul Univ 2001; 34: 9-16.
[20] Şimșek İ, Aytekin F, Yeşilada E, Yıldırımlı Ş. Ankara, Gölbaşı'nda yabani bitkilerin kullanılış amaçları ve şekilleri üzerine bir araştırma. OT Sistematik Botanik Derg 2001; 8, 2:105-20.

[21] Şimşek I, Aytekin F, Yeşilada E, Yıldırımlı Ş. An ethnobotanical survey of the Beypazar1, Ayaş, and Güdül district towns of Ankara province (Turkey). Econ Bot 2004; 58:705-20.

[22] Sarper F, Akaydın G, Şimşek I, Yeşilada E. An ethnobotanical field survey in the Haymana district of Ankara province in Turkey. Turk J Biol 2009; 33:79-88.

[23] Akaydın G, Şimşek I, Arıtuluk ZC, Yeşilada E. An ethnobotanical survey in selected towns of the Mediterranean subregion (Turkey). Turk J Biol 2013; 37:230-47.

[24] Flora of Turkey and The East Aegean Islands, Cilt 1-9. Editör: Davis PH University Press, Edinburg. 1965-1985.

[25] Flora of Turkey and the East Aegean Islands, Cilt 10 (Suppl 1). Editörler: Davis PH, Mill RR, Tan K. Edinburgh University Press, Edinburg. 1988.

[26] Flora of Turkey and The East Aegean Islands, Cilt 11 (Suppl 2). Editörler: Güner A, Özhatay N, Ekim T, Başer KHC. Edinburgh University Press, Edinburg. 2000.

[27] Akaydın G. Doğal Bitkilerimiz. Hacettepe Üniversitesi Yayınları (ISBN: 975-491-148-1), Hacettepe Üniversitesi Hastaneleri Basımevi, Ankara. 2003.

[28] Yeșilada E, Akaydın G, Kırmızıbekmez H. Kayıșdağı'nın Çiçekleri. Yeditepe Üniversitesi (Yayın no: 49, ISBN: 978-975307-039-3), İstanbul. 2008.

[29] Akaydın G. Beytepe Bitkileri. Hacettepe Üniversitesi Yayınları, Ankara. 2009.

[30] Akaydın G. Beytepe Bitkileri. Hacettepe Üniversitesi Yayınları, Ankara. 2011. 